Article

\title{
The influence of positioning deposited beads direction to resistance on grind wear plates' abrasive wear
}

\author{
Michał Szymura1,*, Maciej Różański² \\ 1 Silesian University of Technology, Poland; \\ 2 Łukasiewicz Research Network - Welding Institute, Poland \\ Maciej Różański Ph.D. Eng. maciej.rozanski@is.gliwice.pl; \\ * Correspondence: Michał Szymura M.Sc. Eng. michal.szymura@polsl.pl
}

Received: 10.04.2019; Accepted: 07.05.2019

\begin{abstract}
The article presents the results of the study of the significance of influence of positioning deposited beads towards direction of abrasive movement, to resistance on grind wear plates HARDPLATE 100S' abrasive wear. The study on relevance of influence was conducted by using completely randomized design. The range of study has covered testing the metal-material abrasive wear resistance, macroscopic and microscopic metallographic examination and hardness tests.
\end{abstract}

Keywords: wear plate; hardfacing; abrasion; chromium cast iron; coatings

\section{Introduction}

Existing wear processes limit the operational life of machine parts and equipment. In industry the most common type of wear is abrasive wear (abrasion). It is estimated that it can be responsible for over $60 \%$ of costs resulting from tribological wear $[1 \div 3]$.

Welding technologies enable applying layers and coatings resistant to abrasion. For example, surfacing is used in the production of plates with wear-resistant padding weld (wear-resistant plates), which allow even a few-fold reduction in the wear intensity of machine elements $[1,2,4 \div 13]$.

Commonly, these plates are manufactured by surfacing using wire with a powder core of a layer with specific properties on a structural steel substrate. With the use of additional material that provides the required structure, padding welds are made, which have a high resistance to wear occurring during operation, e.g. abrasion, erosion, abrasion at impact loads and corrosion. The most often padding welds of wear-resistant plates correspond to the composition of high-alloy chromium cast irons, hence they are mainly used to counter abrasion under conditions of intense metal-mineral friction. The wide use of wearresistant plates also results from the possibility of their forming through plastic processing (rolling, bending) and the possibility of assembly through separable (e.g. screw) and inseparable (e.g. welded) connections. In order to ensure adequate dimensional accuracy, objects made of plates with wear-resistant padding welds are shaped by abrasive machining, e.g. by grinding wheels (Fig. 1) [1,6,7,13].

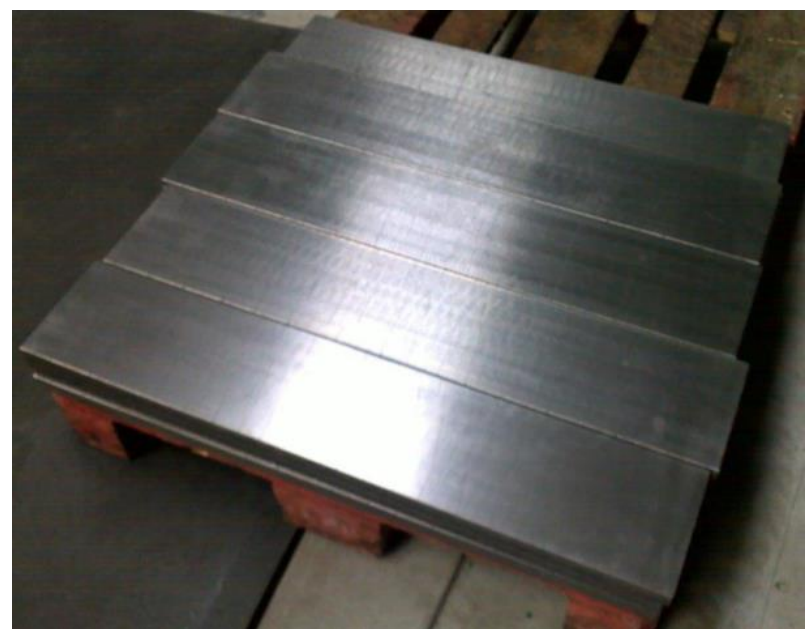

Fig. 1. View of support plates (made from grind wear plates) guide systems in ring-ball mills [13] 
In the technical documentation of the parts of equipment for which the use of plates with ground wear-resistant padding weld is foreseen, the designers determine the direction of beads laid on the surfaced layer or leave the manufacturer the freedom of choice. The qualitative data given in the literature boils down to recommendations regarding the direction of beads of padding welds' beads in relation to the direction of abrasive motion [12]. However, no literature information was found containing quantitative data on abrasion resistance of ground padding welds depending on the position of stitches in relation to the direction of displacement of abrasive elements. Therefore, an attempt was made to determine the influence of the direction of motion of abrasive particles in relation to the direction of the padding weld's beads placement on the abrasion resistance of ground wear-resistant plates.

The paper presents the results of tests for resistance to abrasive wear of the metal-mineral type for different values of angles of setting the beads' direction of plates with ground wear-resistant padding weld HARD-PLATE $100 S 6+4$ produced by Welding Alloys in relation to the flow direction of the abradant. The significance of the impact was determined by conducting studies using a randomized complete statistical program. The scope of the research also included macro and microscopic metallographic examinations as well as measurement of the hardness of the welded layer.

\section{Materials}

HARDPLATE 100S 6+4 wear-resistant plates are manufactured by automatic surfacing with powder self-shielding wire to ensure the alloy of high-alloy Fe15 chromium cast iron according to PN-EN 14700:2014-06, string beads with a layer thickness of approx. $4.0 \mathrm{~mm}$ on a non-alloy steel substrate S235JR according to PN-EN 10025-2:2007 with a thickness of $6.0 \mathrm{~mm}$. These panels are recommended for protecting surfaces exposed to intensive metal-mineral abrasion at moderate impact loads [13].

\section{The course of research}

\section{Abrasion resistance testing}

The research aimed at determining the significance of the impact of the direction of bead placement in relation to the abradant's movement direction on abrasion resistance of ground wear-resistant plates HARDPLATE $100 \mathrm{~S}$ was carried out using a complete randomized static program designed to assess the significance of the influence of one input factor on the output factor [14]. The significance level of influence $\alpha=0.05$ was assumed. The following angle values were adopted between the direction of motion of the abrasive elements and the direction of surfacing of the beads: $0^{\circ}, 30^{\circ}, 45^{\circ}, 60^{\circ}, 90^{\circ}$. For each angle value, 6 abrasion resistance tests of the metal-mineral type were assumed. According to the assumptions and the concept of randomization, 30 sheets of HARDPLATE 100S 64 plates were marked with natural numbers from 1 to 30 based on their production date - from the latest to the earliest produced. Then a sequence of random numbers was obtained using a computer random number generator [15]. Using the generated sequence of numbers, the wear-resistant plates were randomly assigned to the appropriate values of the tested factor. The measurement scheme of a static randomized complete program taking into account the assumptions and assignment is presented in figure 2 [14]. The individual $75 \times 25 \mathrm{~mm}$ samples were cut from the individual wear-resistant plates to ensure that the angle between the longer side of the sample and the direction of the bead placement was $0^{\circ}, 30^{\circ}, 45^{\circ}, 60^{\circ}$ or $90^{\circ}$ (Fig. 3). The location of cracks in the surfaced layer of the samples was accidental. The cut samples were subjected to circumferential disk grinding. In the grinding process, the direction of the feed rate of the tangential table was parallel to the direction of bead placement.

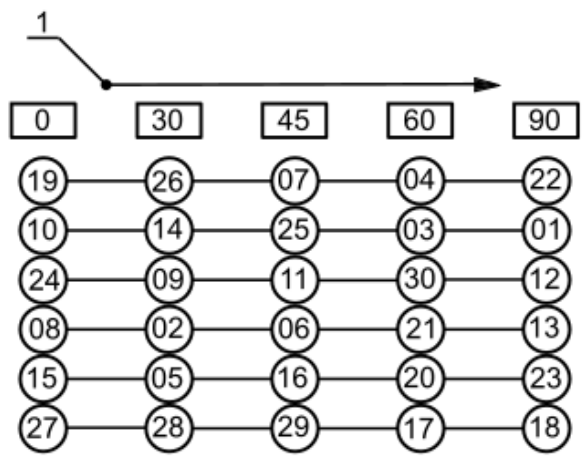

Fig. 2. Scheme of measurements of completely randomized design; 1 - angle between direction of abrasive movement and positioning of deposited beads 

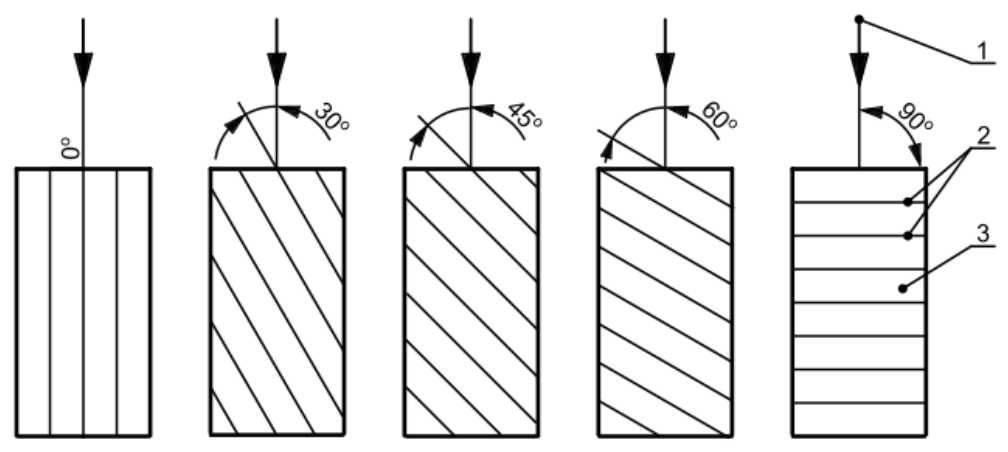

Fig. 3. Positioning of deposited beads of grinding wear plates samples towards direction of abrasive movement; 1 - direction of abrasive movement, 2 - positioning of deposited beads, 3 - grinding wear plates samples

Testing of abrasion resistance of the metal-mineral abrasion of wear-resistant plates was carried out on the basis of ASTM G 65, procedure A. During the test, the abrasive flow rate was $302 \mathrm{~g} / \mathrm{min}$. The samples were loaded with a constant force of $130 \mathrm{~N}$. The friction wheel rotated at $200 \mathrm{rpm}$ and the frictional path was $4309 \mathrm{~m}$. Fire-dried quartz sand with spherical grain and granulation of $100 \div 300 \mu \mathrm{m}$ was used as the abrasive sand. In order to determine the resistance to abrasive wear of padding welds, the loss of mass and density of the padding welds were measured. Samples before and after the study were weighed on laboratory scales with an accuracy of $0.0001 \mathrm{~g}$. The average density of the wear-resistant plate used in the study was determined using a laboratory scale, based on three measurements of the density of the surfaced layer of one sample, weighed in air and liquid. The volume loss was determined using the mass loss values of the sample and the average value of the measured padding weld's density in accordance with formula (1). The results obtained are shown in table I.

$$
\mathrm{U}_{\mathrm{o}}=\frac{\mathrm{U}_{\mathrm{m}}}{\rho} \cdot 1000
$$

where:

$\mathrm{U}_{\mathrm{o}}$ - volume loss, $\mathrm{mm}^{3}$;

$\mathrm{U}_{\mathrm{m}}$ - mass loss, g;

$\rho$ - density, $\mathrm{g} / \mathrm{cm}^{3}$.

Table I. Results of the metal-material abrasive wear resistance test of grinding wear plates samples

\begin{tabular}{|c|c|c|c|c|c|c|c|}
\hline \multirow{2}{*}{$\begin{array}{l}\text { The angle between } \\
\text { the direction of } \\
\text { movement of } \\
\text { abrasive particles } \\
\text { and the direction } \\
\text { of beads } \\
\text { placement, }\end{array}$} & \multicolumn{7}{|c|}{$\begin{array}{l}\text { Loss of the padding weld's volume, } \mathrm{mm}^{3 *} \\
\text { (loss of the padding weld's mass, } \mathrm{g} \text { ) }\end{array}$} \\
\hline & 1 & 2 & 3 & 4 & 5 & 6 & $\begin{array}{c}\text { Average } \\
\text { for individual } \\
\text { levels }\end{array}$ \\
\hline 0 & $\begin{array}{l}19.6682 \\
(0.1432)\end{array}$ & $\begin{array}{l}20.6571 \\
(0.1504)\end{array}$ & $\begin{array}{l}18,2947 \\
(0,1332)\end{array}$ & $\begin{array}{l}22,0305 \\
(0,1604)\end{array}$ & $\begin{array}{l}20,7669 \\
(0,1512)\end{array}$ & $\begin{array}{l}19,2561 \\
(0,1402)\end{array}$ & $\begin{array}{l}20,1123 \\
(0,1464)\end{array}$ \\
\hline 30 & $\begin{array}{l}20.8906 \\
(0.1521)\end{array}$ & $\begin{array}{l}22.8409 \\
(0.1663)\end{array}$ & $\begin{array}{l}19,5583 \\
(0,1424)\end{array}$ & $\begin{array}{l}21,4125 \\
(0,1559)\end{array}$ & $\begin{array}{l}20,3137 \\
(0,1479)\end{array}$ & $\begin{array}{l}23,2941 \\
(0,1696)\end{array}$ & $\begin{array}{l}21,3850 \\
(0,1557)\end{array}$ \\
\hline 45 & $\begin{array}{l}20.0527 \\
(0.1460)\end{array}$ & $\begin{array}{l}20.7532 \\
(0.1511)\end{array}$ & $\begin{array}{l}20,3824 \\
(0,1484)\end{array}$ & $\begin{array}{l}18,3222 \\
(0,1334)\end{array}$ & $\begin{array}{l}22,0168 \\
(0,1603)\end{array}$ & $\begin{array}{l}20,2176 \\
(0,1472)\end{array}$ & $\begin{array}{l}20,2908 \\
(0,1477)\end{array}$ \\
\hline 60 & $\begin{array}{l}20.7257 \\
(0.1509)\end{array}$ & $\begin{array}{l}20.7669 \\
(0.1512)\end{array}$ & $\begin{array}{l}20,0390 \\
(0,1459)\end{array}$ & $\begin{array}{l}22,5250 \\
(0,1640)\end{array}$ & $\begin{array}{l}19,0776 \\
(0,1389)\end{array}$ & $\begin{array}{l}20,6296 \\
(0,1502)\end{array}$ & $\begin{array}{l}20,6273 \\
(0,1502)\end{array}$ \\
\hline 90 & $\begin{array}{l}22.1542 \\
(0.1613)\end{array}$ & $\begin{array}{l}20.1764 \\
(0.1469)\end{array}$ & $\begin{array}{l}22,7722 \\
(0,1658)\end{array}$ & $\begin{array}{l}19,8193 \\
(0,1443)\end{array}$ & $\begin{array}{l}22,4975 \\
(0,1638)\end{array}$ & $\begin{array}{l}19,3660 \\
(0,1410)\end{array}$ & $\begin{array}{l}21,1309 \\
(0,1539)\end{array}$ \\
\hline & \multicolumn{6}{|c|}{ For all results } & $\begin{array}{l}20.7093 \\
(0.1508)\end{array}$ \\
\hline
\end{tabular}

${ }^{*}$ loss of the padding weld's volume was determined according to the formula (1).

Measured density of the padding weld of wear-resistant plate HARDPLATE $100 \mathrm{~S} 6+4$ is $7,2808 \mathrm{~g} / \mathrm{cm}^{3}$

According to the implementation scheme of the randomized complete statistical program, an analysis table of variance was created (Table II) 
Table II. Analysis of variance table

\begin{tabular}{|c|c|c|c|c|}
\hline Name & $\begin{array}{c}\text { Sum of squares } \\
\text { S }\end{array}$ & $\begin{array}{c}\text { Number of degrees } \\
\text { of freedom } \mathbf{f}\end{array}$ & $\begin{array}{l}\text { Average square } \\
\mathbf{s}^{2}\end{array}$ & $\begin{array}{c}\text { Value } \\
\text { of the test } F\end{array}$ \\
\hline $\begin{array}{l}\text { Between } \\
\text { systems }\end{array}$ & $S_{M U}=\sum_{i=1}^{K} r_{i} \bar{y}_{i}^{2}-N \bar{y}^{2}=7.03599$ & $f_{M U}=K-1=4$ & $s_{M U}^{2}=\frac{S_{M U}}{K-1}=1.7590$ & $\begin{array}{l}F=\frac{S_{M U}^{2}}{S_{W U}^{2}} \\
=0.9993\end{array}$ \\
\hline $\begin{array}{l}\text { Inside } \\
\text { the system }\end{array}$ & $\begin{array}{r}S_{W U}=\sum_{i=1} \sum_{j=1} y_{i j}^{2}-\sum_{i=1} r_{i} \bar{y}_{i}^{2} \\
=44.00543\end{array}$ & $f_{W U}=N-K=25$ & $s_{W U}^{2}=\frac{S_{W U}}{N-K}=1.7602$ & - \\
\hline Rest & $S_{R}=\sum_{i=1} \sum_{j=1} y_{i j}^{2}-N \bar{y}^{2}=51.04142$ & $f_{R}=N-1=29$ & - & - \\
\hline
\end{tabular}

where:

$\mathrm{r}_{\mathrm{i}}$ - the number of measurements of the input factor at a given level; $\mathrm{N}$ - total number of measurements of the input factor;

$\bar{y}_{i}$ - average of measurement results; $\mathrm{y}^{-}$- average of results from all measurements;

$\mathrm{y}_{\mathrm{ij}}$ - the value of the $\mathrm{j}$-th resultative factor at the i level; $\mathrm{K}$ - number of variability levels of the tested factor

\section{Hardness measurements}

Measurements of hardness of layers of surfaced samples from ground wear-resistant plates were carried out on the surface of the padding weld's face using the Rockwell method (Fig. 4a) and for 2 samples on the cross-sectional area of the plate in the area of the overlap of the padding weld beads, heat affected zone and basic material using the Vickers method (Fig. 4b). The results of hardness measurements obtained are presented in table III, IV and V.

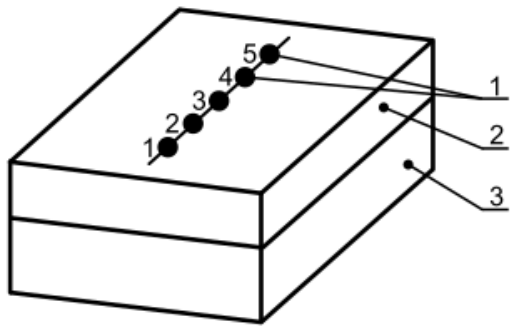

(a)

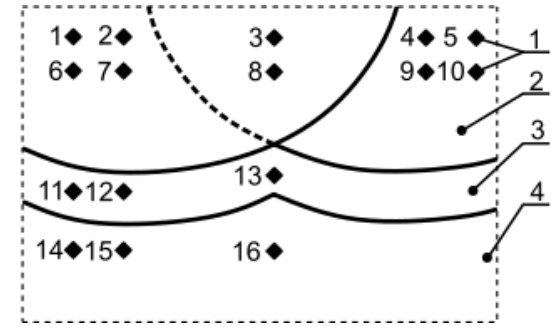

(b)

Fig. 4. Hardness tests points distribution: a) on the face of overlay weld of grind wear plates; 1 - hardness test points, 2 - grinding hardfacing deposit, 3 - base material, b) on the surface of grinding wear plates' cross section; 1 hardness test points, 2 - grinding hardfacing deposit, 3 - heat affected zone, 4 - base material

\section{Metallographic examinations}

In order to determine the quality of the surfaced layer, micro- and macroscopic metallographic examinations were performed. Metallographic examination of the sample with the number 19, whose angle between the longer side of the sample and the direction of beads placement is $0^{\circ}$, was carried out on transverse metallographic specimen using a light microscope. The results of macroscopic metallographic examinations are presented in figure 5a, and metallographic microscopic findings in figure $5 \mathrm{~b}$.

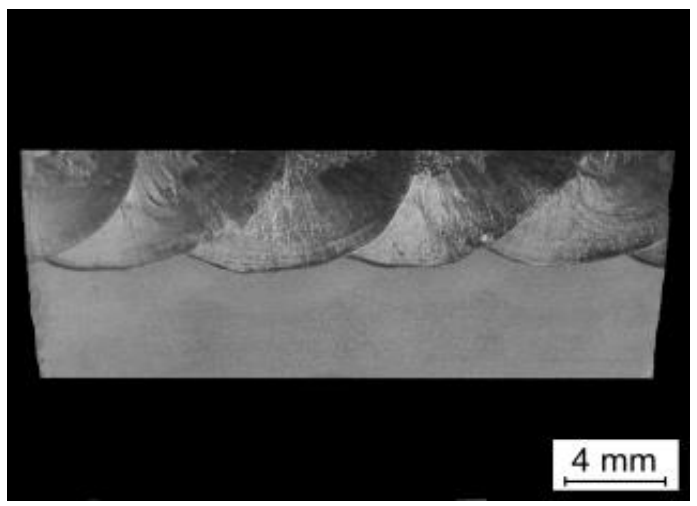

(a)

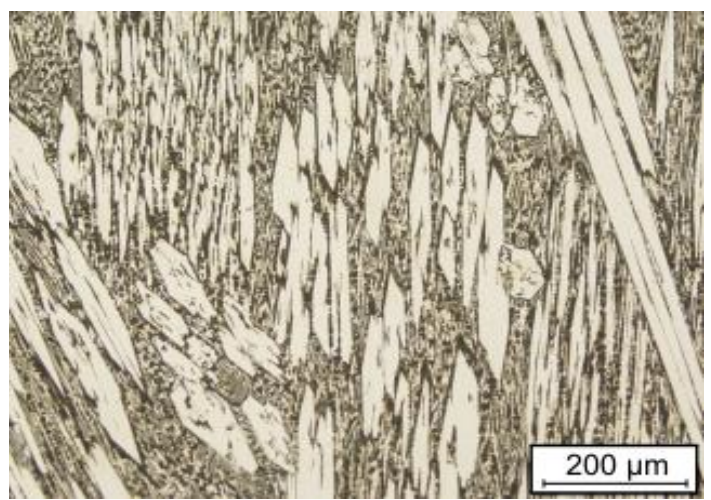

(b)

Fig. 5. a) The macrostructure of grinding wear plate HARDPLATE $100 S^{\prime} 6+4 ; b$ ) and microstructure of hardfacing deposit of this plate 
Table III. Results of HRC hardness measurements on the face of hardfacing deposit samples of grinding wear plates

\begin{tabular}{|c|c|c|c|c|c|c|c|}
\hline \multirow{2}{*}{$\begin{array}{l}\text { Sample } \\
\text { number }\end{array}$} & \multirow{2}{*}{$\begin{array}{c}\text { Angle between } \\
\text { the longer side of the } \\
\text { sample and the direction } \\
\text { of beads placement, }{ }^{\circ}\end{array}$} & \multicolumn{5}{|c|}{ Hardness measurement point * } & \multirow{2}{*}{$\begin{array}{c}\text { Average value } \\
\text { of the } \\
\text { hardness of } \\
\text { the sample, } \\
\text { HRC }\end{array}$} \\
\hline & & 1 & 2 & 3 & 4 & 5 & \\
\hline 19 & 0 & 59.5 & 61.0 & 62.5 & 61.5 & 59.5 & 60.8 \\
\hline 10 & 0 & 59.0 & 60.0 & 62.5 & 61.0 & 60.5 & 60.6 \\
\hline 24 & 0 & 60.5 & 61.0 & 61.5 & 61.5 & 59.5 & 60.8 \\
\hline 08 & 0 & 59.5 & 60.0 & 60.5 & 61.0 & 61.0 & 60.4 \\
\hline 15 & 0 & 58.5 & 59.5 & 61.0 & 60.0 & 61.0 & 60.0 \\
\hline 27 & 0 & 62.5 & 62.5 & 60.5 & 59.5 & 60.0 & 61.0 \\
\hline 26 & 30 & 58.5 & 60.0 & 60.5 & 60.5 & 60.0 & 59.9 \\
\hline 14 & 30 & 60.5 & 60.0 & 61.5 & 60.5 & 61.0 & 60.7 \\
\hline 09 & 30 & 60.5 & 59.0 & 62.0 & 61.0 & 61.0 & 60.7 \\
\hline 02 & 30 & 59.5 & 61.5 & 60.5 & 60.0 & 60.5 & 60.4 \\
\hline 05 & 30 & 59.5 & 61.0 & 62.5 & 62.0 & 60.5 & 61.1 \\
\hline 28 & 30 & 59.5 & 60.0 & 60.5 & 62.0 & 61.0 & 60.6 \\
\hline 07 & 45 & 61.5 & 62.0 & 59.0 & 60.5 & 60.0 & 60.6 \\
\hline 25 & 45 & 60.5 & 61.5 & 61.0 & 62.0 & 60.5 & 61.1 \\
\hline 11 & 45 & 60.0 & 59.0 & 60.5 & 61.0 & 60.5 & 60.2 \\
\hline 06 & 45 & 60.5 & 59.5 & 61.0 & 61.0 & 58.5 & 60.1 \\
\hline 16 & 45 & 60.5 & 60.5 & 61.0 & 60.5 & 60.0 & 60.5 \\
\hline 29 & 45 & 60.5 & 61.0 & 60.5 & 60.0 & 59.0 & 60.2 \\
\hline 04 & 60 & 59.0 & 61.5 & 60.5 & 62.0 & 60.5 & 60.7 \\
\hline 03 & 60 & 61.0 & 62.0 & 60.0 & 60.0 & 59.5 & 60.5 \\
\hline 30 & 60 & 60.5 & 61.0 & 62.0 & 60.5 & 59.5 & 60.7 \\
\hline 21 & 60 & 60.0 & 58.5 & 60.5 & 60.5 & 60.0 & 59.9 \\
\hline 20 & 60 & 61.5 & 61.5 & 59.5 & 60.0 & 59.5 & 60.4 \\
\hline 17 & 60 & 59.5 & 60.0 & 61.0 & 60.0 & 61.0 & 60.3 \\
\hline 22 & 90 & 58.5 & 59.0 & 59.5 & 61.0 & 60.5 & 59.7 \\
\hline 01 & 90 & 62.0 & 60.5 & 60.0 & 61.0 & 59.0 & 60.5 \\
\hline 12 & 90 & 60.0 & 60.5 & 60.5 & 60.5 & 59.0 & 60.1 \\
\hline 13 & 90 & 59.5 & 61.5 & 62.0 & 60.0 & 60.0 & 60.6 \\
\hline 23 & 90 & 61.0 & 61.5 & 60.0 & 58.5 & 59.9 & 60.2 \\
\hline 18 & 90 & 60.0 & 62.0 & 62.0 & 59.5 & 60.0 & 60.7 \\
\hline
\end{tabular}

${ }^{*}$ marking of measurement points in accordance with figure $4 \mathrm{a}$

Table IV. Results of HV30 hardness measurements on cross section of hardfacing deposit samples of grinding wear plates

\begin{tabular}{|c|c|c|c|c|c|c|c|c|c|c|c|}
\hline \multirow{2}{*}{$\begin{array}{l}\text { Sample } \\
\text { number }\end{array}$} & \multirow{2}{*}{$\begin{array}{l}\text { Angle between the longer side } \\
\text { of the sample and the } \\
\text { direction of beads placement, }{ }^{\circ}\end{array}$} & \multicolumn{10}{|c|}{ Hardness measurement point * } \\
\hline & & 1 & 2 & 3 & 4 & 5 & 6 & 7 & 8 & 9 & 10 \\
\hline 19 & 0 & 804 & 711 & 761 & 814 & 754 & 825 & 709 & 729 & 791 & 803 \\
\hline 10 & 0 & 747 & 746 & 703 & 784 & 697 & 728 & 688 & 747 & 759 & 812 \\
\hline
\end{tabular}

${ }^{*}$ marking of measurement points in accordance with figure $4 \mathrm{~b}$

Table V. Results of HV10 hardness measurements on cross section of heat affected zone and base material samples of grinding wear plates

\begin{tabular}{cccccccc}
\hline $\begin{array}{c}\text { Sample } \\
\text { number }\end{array}$ & $\begin{array}{c}\text { Angle between the longer side } \\
\text { of the sample and the direction } \\
\text { of beads placement, }\end{array}$ & $\mathbf{5}$ & $\mathbf{1 2}$ & $\mathbf{1 3}$ & $\mathbf{1 4}$ & $\mathbf{1 5}$ & $\mathbf{1 6}$ \\
\cline { 3 - 8 } & 0 & 174 & 185 & 167 & 150 & 163 & 152 \\
19 & 0 & 177 & 170 & 161 & 148 & 154 & 141 \\
\hline
\end{tabular}

* marking of measurement points in accordance with figure $4 \mathrm{~b}$ 


\section{Analysis of research results}

The conducted tests of abrasion resistance of ground wear-resistant plates HARDPLATE 100S showed that regardless of the direction of bead placement in relation to the direction of movement of abradant, the surfaced layer is characterized by high resistance to abrasion. The average loss of padding weld's volume determined based on ASTM G 65 for particular values of bead angles is in the range of 20.1123: $\div 21.3850 \mathrm{~mm}^{3}$. The significance of the impact study was conducted using a randomized complete statistical program. The value of the $\mathrm{F}$ test calculated on the basis of statistical analysis of test results (Table II) is less than the critical value F0.05; 4; F Fischer-Snedecor F test [14]. It authorizes us to state that for the adopted level of significance and the calculated number of degrees of freedom, the direction of bead placement in relation to the direction of movement of abrasive particles does not significantly affect the abrasion resistance of the metal-mineral type of plates with ground wear-resistant padding weld.

The hardness measurements carried out on the face of the padding weld of ground wear-resistant plates show high hardness of the surfaced layers and high repeatability of results irrespective of the direction of bead placement with respect to the longer side of the sample. The average hardness values of individual samples are in the range of $59.7 \div 61.1 \mathrm{HRC}$, while the gap is $4.0 \mathrm{HRC}$. There was no deterioration of the padding weld's hardness in the bead joints zone. The hardness measured on the cross-sectional area of the padding weld is within $688 \div 825 \mathrm{HV} 30$, and in the area of the beads' overlap $703 \div 761 \mathrm{HV} 30$. The heat affected zone has a hardness of $161 \div 185$ HV10, while the base material $141 \div 163$ HV10. In both cases, the measured hardness does not exceed the maximum permissible hardness of $380 \mathrm{HV} 10$ according to PN-EN ISO 15614-7:2016-12 for steel from material group 1.

The metallographic tests carried out did not indicate the occurrence of welding defects in the surface layer of the plate with wear-resistant padding weld. The surfaced layer is properly connected to the base material and the penetration has a regular circular shape. On the basis of microscopic examination, it can be concluded that the padding weld of the wear-resistant plate probably has a structure composed of large chromium carbides in the austenitic matrix.

\section{Resources}

[1] Bęczkowski R., Selected issues of applying a wear-resistant plates in the mining industry. Welding Technology Review, 2017, Vol. 89(5), 80-84. [CrossRef]

[2] Mucha T., Bartkowiak K., Application of cladded abrasive-resistant plates in repairs of opencast mining equipment. Welding Technology Review, 2011, Vol. 83 (10), 73-76. [Crossref]

[3] Neale M., Gee M., A guide to wear problems and testing for industry, William Andrew, 2001, 3-8.

[4] Ban M., Hasegawa N., Ueno Y., Shinozaki H., Aoki T., Fukumoto H., Wear Resistance Property of Hardfacing Weld Overlays Containing Metal Carbides. Tribology Online 2012, Vol. 7(4), 207-212. [CrossRef]

[5] Czupryński A., Properties of $\mathrm{Al}_{2} \mathrm{O}_{3} / \mathrm{TiO}_{2}$ and $\mathrm{ZrO}_{2} / \mathrm{CaO}$ flame sprayed coatings. Spajanie Materiałów Konstrukcyjnych, 2017, Vol. 36(2), 32-39.

[6] Czupryński A., Kik T., Melcer M., Comparison of abrasion resistance of wear plates. Welding Technology Review, 2018, Vol. 90(5), 28-36. [CrossRef]

[7] Klimpel A., Górka J., Czupryński A., Comparison of chromium cast iron deposits of wear plates. Journal of Achievements in Materials and Manufacturing Engineering, 2006, Vol. 18(1-2), 387-390. [Hyperlink]

[8] Pawar S., Mukhopadhyay G., Metallurgical and Tribological Evaluation of Fe-Cr-C Hardfacing Alloys. Journal of Failure Analysis and Prevention, 2018, Vol. 18(4), 868-876. [Hyperlink]

[9] Turyk E., Riabcew I.A., Melcer M., Rebuilding of coils of screw conveyors with chromium cast iron hard laye., Welding Technology Review, 2018, Vol. 90(9), 24-27. [CrossRef]

[10] Varga M., High temperature abrasive wear of metallic materials. Wear, 2017, Vol. 376-377, 443-451. [CrossRef]

[11] Yury K., Filippov M., Makarov A., Malygina I., Soboleva N., Fantozzi D., Adrea M., Koivuluoto H., Vuoristo P., Arc-Sprayed Fe-Based Coatings from Cored Wires for Wear and Corrosion Protection in Power Engineering. Coatings, 2018, Vol. 8(2), 71. [CrossRef]

[12] Ziemliński J., Simplified technology of welding large working surfaces exposed to the destructive effect of loose materials. (in-polish) Biuletyn Instytutu Spawalnictwa, 1966, Vol. 28, 28-32.

[13] Welding Alloys Polska Sp. z o.o., Pad welded wear plates, WA, 2018.

[14] Kukiełka L., Basics of engineering research. PWN, 2002, 40-42, 248.

[15] https://www.random.org/sequences/?min=1\&max=30\&col=1\&format=html\&rnd=new (30.01.2019)

(C) 2019 by the authors. Submitted for possible open access publication under the terms and conditions of the Creative Commons Attribution (CC BY) license (http://creativecommons.org/licenses/by/4.0/). 